with this extra money," said one OSTP official. "Firstly to help underpin the general research base of the private sector. And secondiy to support research, orientated towards the products and processes that are likely to be in place in the next few years."

According to Dr Press, the commitment to additional funds will "restore and go beyond the cutbacks proposed last March, which appeared to wipe out any hope of a real growth in support for basic research in the immediate future".

So far the scientific community has given the announcement a cautious welcome, but is waiting until more specific details are announced in the President's budget request next January - if he is re-elected before passing judgement.

Although the total amount of funds may be small in comparison with the total US research and development effort, their effectiveness will depend on the way they are packaged. According to Dr Jack Crowely of the Association of American Universities "if they are willing to make some difficult decisions and focus funds in high priority areas, then they could achieve quite a bit."

Little direct reference has been made to research funding in the platform statements of the two main political parties. However the Republican statement does refer to the need to increase support for research and development as part of a general effort to increase US military strength.

David Dickson

NIH funding

\section{Congress control Washington}

Despite intense opposition from the biomedical research community, the House of Representatives last week passed a bill which would, for the first time, give it direct responsibility for the budgets and research programmes of nine out of the eleven National Institutes of Health.

At present only two of the institutes the National Cancer Institute and the National Heart, Lung and Blood Institute - are covered by specific authorizing legislation. The others fall within the broad responsibilities of the Department of Health and Human Resources.

The new bill sets generous budget ceilings for the various institutes, each of which would have its budget authorized by Congress every three years. Overall, the bill recommends a 27 per cent increase in the NIH budget in 1981 to a total of $\$ 4,076$ million, almost twice the budget increase proposed in the appropriations bill which was also passed last week (see page 3).

However, the implications of the legislation are that Congress will be in a position to exert more direct control over the research programmes of the nine institutes which currently are not controlled by separate legislation. And it is this which has given rise to strong opposition from universities, medical schools and professional associations.

Writing in the Washington Post on 25 August, for example, two days before the vote took place on the bill, the past four directors of NIH stated "We are convinced that a long-term federal commitment to research is far and away best served by permanent authority of the type contained in . . . the Public Health Service Act."

The bill has been opposed by the American Association of Medical Colleges, the Association of Professors of Medicine, and the Joint Health Committee of the Association of American Universities. It has also been the source of fierce controversy within the administration. Initially it was opposed by Health Secretary Mrs Pat Harris, who argued that existing legislation was adequate to ensure a high standard of medically important research. Subsequently, however, after various modifications to the bill, the administration agreed to support the new legislation.

NIH administrators, who had previously been among those in opposition, were instructed to hold to the party line (Nature, 22 May 1980). And when the bill was introduced last week by Representative Henry Waxman, chairman of the health and environment subcommittee of the House Interstate and Foreign Commerce Committee, he said that both Dr Donald Fredrickson, director of NIH, and Dr Julius Richmond, the Surgeon General, had written giving their support.

Scientists fear that, by giving Congress access to detailed decisions on research priorities, the process could become overpoliticized, encouraging short-sighted mandates to explore applied uses of research at the expense of basic research. However, during last week's debate on the bill, a number of congressmen spoke of the need to be in close contact with NIH, programmes.

Despite an intense lobbying campaign by university and medical school scientists, the proposed legislation was passed in the House by 292 votes to 48 . It must now be reconciled with a counterpart bill which has been approved by the Senate, promoted by Senator Edward Kennedy.

This does not create authorizing legislation for all NIH institutes, but mandates the creation of a Presidential Commission on Biomedical Research with broad responsibilities to oversee medical research priorities.

\section{Soviet academics}

\section{Wasted talent}

Soviet planning is still not making sufficient use of the academic potential of the country, according to V. KirillovUgryumov, Chairman of the Higher Attestation Commission (Vysshaya
Atestatsionnaya Komissiya-VAK) of the Council of Ministers of the USSR. In a Pravda article reviewing the work of VAK over the last five years, he pointed out shortcomings not only in VAK's work of awarding higher degrees, but also in the use made of the content of theses. The annual surveys, provided by VAK, of the content of theses and research projects, are not being utilized by the ministries and planning bodies concerned, and the recommendations made to the State Publishing Commission concerning the publication of the most interesting and significant theses are not being implemented. All this, he says, hinders the implementation of research results in the economy. The problem, moreover, is a particularly pressing one now that the country is on the threshold of the TwentySixth Party Congress which will approve the directives for the next five-year plan.

Not, however, that VAK itself escapes without criticism. Six years ago the Central Committee of the Communist Party of the Soviet Union (CPSU) and the Council of Ministers of the USSR approved a resolution which overhauled the whole system of awarding higher degrees, in particular setting up a network of expert councils to assess theses submitted to them. Not all these councils, said KirillovUgryumov, are functioning properly. In 1979 the presidium of VAK had to return no less than 256 works to the relevant councils since the reports on them were "insufficiently clear or well-grounded". Occasionally "ill-will" is creeping into the work of the councils, interfering with objective scientific assessment, and creating a situation resembling a court of law. Kirillov-Ugryumov goes on to decry "subjectivism and red-tape at any stage of the attestation process".

Nowhere in his article does KirillovUgryumov mention a clause in the 1976 Resolution which many Soviet academics found disturbing - the stipulation that the postulants must satisfy VAK not only with the worth of their theses but also with their political record. Indeed, his criticism that certain expert councils have been letting "weak theses" through, and that steps must be taken to remedy this may well be a veiled criticism of councils which look over-leniently on the mediocre efforts of the scions of high party officials. However, a samizdat essay by Grigori Freiman recently republished in the West, "It seems I am a Jew" contains what is claimed to be a stenographic transcript of an "expert council" meeting, in which remarkable feats of dialectic are produced to find some reason, other than the postulant's Jewishness, to reject a thesis which all participants know in advance cannot be accepted. If Freiman is to be believed and at the time of writing he was a Professor of the Kalinin State University, and a member of the CPSU - the political clause is apparently being applied under some other guise.

Vera Rich 